fantasies so that the experience becomes a constructive and not a destructive one. If a hypnotic approach is being used it is possible to utilize the necessary interviews with the child before and after the procedure to promote this. It is, of course, well known that satisfactory analgesia cannot be achieved in all cases by the use of a hypnotic technique, and when suggestions of absence of pain have been unsuccessful insecurity in the dental situation must be increased. In actual fact, paediatric anaesthetists frequently use a hypnotic type of induction to general anaesthesia, although not all would use the term "hypnosis."

\section{Inheritance of Ichthyosis}

Q.-Two young people planning to get married both suffer from ichthyosis. In addition, the boy suffers from asthma and eczema. The boy is the only case in his family but the girl has a history of ichthyosis down one side of her family. What are the possibilities of illness for the children of such a marriage?

A.-There are probably two independent risks to children of this couple; a fairly high risk of inheriting ichthyosis vulgaris from the mother, and a small risk of inheriting the father's ichthyosis with asthma and eczema. Uncomplicated ichthyosis may be due to several different genes, but here, since it is present in a girl and in more than one generation of her family, the gene concerned is probably a dominant with a fairly high rate of manifestation. Ichthyosis in association with eczema and asthma, in many instances at least, appears to be due to an autosomal recessive gene and, though instances of transmission to a second generation are known, they are not the rule. ${ }^{1}$

\section{REFERENCE}

1 Touraine, A., L'Hérédité en Médecine, 1955. Masson, Paris.

\section{Vernal Conjunctivitis}

Q.-Vernal conjunctivitis, or spring catarrh, is frequently resistant to local cortisone therapy. I believe that some American authorities have claimed that lactic acid and adrenaline drops are of benefit-is this so and what is their composition? Is there any other treatment that stands a reasonable chance of success?

A.- Cases of vernal conjunctivitis which do not respond to local cortisone may sometimes respond to systemic cortisone. $\beta$-radiation has been claimed to be of value, and mucous grafting to the denuded tarsal plate has been suggested. Pollen sensitivity can be demonstrated in some cases and good results have been claimed for specific desensitization. Prednisone has been found the most effective steroid. ' The treatment with lactic acid was suggested by Barradah. ${ }^{2}$ The drops contained 1-2\% tetracaine hydrochloride, $1 \%$ of 1:1,000 epinephrine, and 1\% lactic acid in distilled water. A full discussion of vernal conjunctivitis and its treatment can be found in a book by Beigelman. ${ }^{3}$

\section{REFERENCES}

1 Neumann, E., Brit. J. Ophthal., 1958, 42, 674

- Barradah, M. A. E., Bull. ophthal. Soc. Egypt, 1956, 49, 115

- Beigelman, M. N. Vernal Conjunctivitis, 1950. Los Angeles, University of Southern California Press.

\section{Pregnancy Hazards in Radiographers}

Q.-Is it advisable for a married radiographer to stop work before becoming pregnant, or to stop work as soon as she becomes pregnant? She works a 36-hour week and her personal exposure disk readings vary from 0 to 15 milliRoentgens per three weeks.

A.- The recommendations of the International Commission on Radiological Protection do not debar women, including pregnant women, from following their normal occupation in radiology. Although the embryo, particularly at the period of morphogenesis in the early weeks of pregnancy, is highly radiosensitive and any damage is likely to result in morphological disorder, it is considered that the probability of induction of such morphological change by the very low doses now permitted in radiological occupations is so low that it can be neglected. It must be remembered that the proportion of all newborn infants that show spontaneously morphological deviation from what is taken to be normal is relatively high-some $5 \%$. This high rate of natural aberration is due to manifestation of spontaneously occurring genetic mutation and to intrauterine environmental causes.

Since the dose-rate to which the radiographer in question is exposed is at maximum only some $5 \%$ of the permitted weekly dose for radiographers, there can be no compelling reason to advise her to give up her occupation before pregnancy occurs or after it is confirmed.

\section{NOTES AND COMMENTS}

Chest X-ray in Pregnancy.-Dr. G. R. AIRTH (Southmead Hospital, Bristol) writes: Would the author of the answer to this question ("Any Questions ?" August 13, p. 551) be good enough to enlarge on his statement that the incidence of tuberculosis in young pregnant women is still about 2 per 1,000 ? Does he refer to tuberculosis of proven activity, or does he include the quiescent and apparently healed lesion? If all are included, the incidence may well be as stated; if active tubercle is being considered, 1 think that the incidence is very much smaller than 2 per 1,000 . Having been instrumental in starting the chest radiography service in this area over 10 years ago, I am very concerned to find it so misused in 1960. At a time when the number of active tuberculous lesions was considerable, the intention was to segregate patients in an observation ward, away from uninfected maternity cases. I can find no evidence that any significant number of tuberculous lesions worsen during pregnancy, but it is common knowledge that they may do so after delivery. Very few lesions indeed are found initially by routine antenatal chest radiography-i.e., when the patient has no symptoms of chest disease. The logical time to examine the chest seems to be at a foetal age of 36 weeks or later, to provide early warning of danger to the baby or other mothers in a hospital ward, and of the need for close observation of the mother herself after delivery. I see no valid reason for chest $x$-ray examination early in pregnancy.

OUR EXPERT replies: The last Ministry of Health report from the mass radiography units examining women during the antenatal period found the incidence of active tuberculosis requiring treatment at 1.6 per 1,000 . Another 1.6 per 1,000 were found to require careful supervision in the chest clinics.

Corrections. - The last five lines of the paper by Drs. David Phear and William C. Walker (October 1, p. 995) should have read as follows: "However, in a recent trial of $\beta$-phenylisopropyl-hydrazine ('cavodil ') MacKinnon et al. (1960) found worthwhile improvement of angina. Our experience has been less encouraging. Hepatic damage with jaundice developed in one of 12 patients treated with cavodil."

We much regret a printing error in the second paragraph of the summary of the paper entitled "Disinfection of the Skin of Operation Sites" by Dr. E. J. L. Lowbury, Mr. H. A. Lilly, and Dr. J. P. Bull (Journal, October 8, p. 1039). We printed "Iodine $1 \%$ in alcohol had approximately the same effect. ..." This should have read "Iodine 1\% in alcohol and chlorhexidine $(0.5 \%)$ in alcohol had approximately the same effect. . .'

Collected Articles from the "British Medical Journal"

The following books are available through booksellers or from the Publishing Manager, B.M.A. House. Prices, which include postage, are now the same for both inland and overseas.

Refresher Course for General Practitioners, Volume 3 (26s. 9d.). Clinical Pathology in General Practice (22s. 3d.).

Any Questions?, Volume 3 (8s. 3d.).

All communications with regard to editorial business should be addressed to THE EDITOR. BRITISH MEDICAL JOURNAL, B.M.A. HOUSE, TAVISTOCT SQUARE, LONDON, W.C.1. TELEPIONE: EUSTON 4499. TELEGRAMS : Aitiology, W estcen, London. ORIGINAL ARTICLES AND LETTERS

Authors desiring REPRINTS should communicate with the Publishing Manager. B.M.A. House, Tavistock Square, W.C.1, on receipt of proofs. DVERTISEMENTS should be addressed to the Advertisement Director, B.M. A. Ilouse, Tavistock Square. London, W.C.1 (hours 9 a.m. to 5 p.m.). TELFPHONE: EUSTON 4499. TELEGRAMS: Britmedads, Westcent, London.
MEMBERS the Association. TELEPHONE: EUSTON 4499. TELEGRAMS: Medisecra,
to the Association.

B.M.A. Scotrish OfFice: 7, Drumsheugh Gardens, Edinburgh. 